\title{
Accounting
}

\section{Days inventory outstanding and firm performance: Empirical investigation from manufacturers}

\author{
Khaled Aljaaidi $^{a^{*}}$ and Omar Ali Bagais ${ }^{a}$
}

\author{
$\frac{{ }^{a} \text { Accounting Departm }}{\text { C H R O N I C L E }}$ \\ Article history: \\ Received May 152020 \\ Received in revised format May \\ 162020 \\ Accepted July 62020 \\ Available online \\ July 102020 \\ Keywords: \\ $D I O$ \\ Firm performance \\ Saudi Arabia
}

\section{Introduction}

Inventory that is well managed can have some great impact on the profits of a company due to the ability of the company to recognize areas for reducing the cost of storage of tock and ensure that there is a smooth flow in production activities (Cheung et al., 2004). Bourne and Walter (2005) state that there is a direct relationship between proper management of inventory and the performance of a company (Lambert et al., 2005; Marota et al., 2017). When companies practice inadequate inventory management techniques it is obvious that the result there is an increase in waste due to the increase in the cost of storing inventory and the pronounced risk of exposing the inventory to damages or losses (Lwiki et al., 2013). Therefore, effective performance can be achieved if companies can develop strategies for attaining the maximum possible revenue within the minimum cost. For instance, in some cases attaining the best solutions for managing inventory can have a direct influence on the company's layout and in turn influence the profitability and performance (Fullerton \& Wempe, 2003; Swamidass, 2007; Koumanakos, 2008; Steven \& Britto, 2016; Lin et al., 2018). Of note is that, since there is a direct relationship between inventory management and the return on assets (ROA) (Eroglu \& Hofer, 2011; Sahari et al., 2012; Nguyen, 2020). Companies are usually encouraged to keep the inventory within optimal levels if they expect to attain significant improvements in managing the performance of financial resources (Abd Karim et al., 2018). Some areas where inventory management has a direct impact on company performance include supply chain management. Supply chain management is a crucial activity that usually involves all activities surrounding the transferring of goods and raw materials from the producer to the consumer. In this case, inventory management allows smooth flow of supply chain activities by ensuring the proper selection of resources and supplies, clarity if production scheduling, efficient order processing, the seamless management of inventory by facilitating the transfer and storage activities, and finally ensuring valuable customer service is delivered (Burgess et al., 2006). The impact of proper inventory

* Corresponding author.

E-mail address: k.aljaaidi@psau.edu.sa (K. Aljaaidi) 
management is that it can guarantee better control over the company's cash management. Companies that have succeeded in their business by implementing proper inventory management tend to grasp better techniques for attaining efficiency of cash management. The problem that lies with the unsuccessful companies is that they embrace poor cash management techniques or sometimes experience consistent shortages in cash budget that usually cause significant consequences such as loss of cash discount, attaining bad reputation due to delays in meeting payment demands on time and sometimes insolvency of a company in case of absolute bankruptcy that could easily provoke the company's shutdown (Tuller, 2008; Jarrad, 2000). Therefore, it is important to have a good cash management system in place that can guarantee a company to have better control of financial risks, exploit opportunities for making profits, and facilitate a better balance sheet for the company. If all this can be achieved through proper cash management then a company should have confidence that the chances of improving operational efficiency are high (Abioro, 2013; Gallagher, 2002). Some ways of measuring if the inventory management is contributing to the efficiency of a company's financial performance are by monitoring the days of inventory outstanding (DIO). Evaluating the DIO can help to assess the level of inventory control attained in a company. It does so by illustrating the level of inventory required for storing at a given time and also provides a record of inventories available within a given period (Mauchi et al., 2011). Therefore, if a company experiences reduction in DIO it is an indication that the company is improving in managing its working capital that also translates positively to the company's profitability margins (Tradecko, 2020; Warrad \& Khaddam, 2020). Empirically, Abioro (2013) and Mauchi et al. (2011) found that there is a positive relationship between the efficiency of cash management policies and the overall business performance. Abioro (2013) and Platt (2003) found that there is a positive relationship between the level of cash flow and the profitability of the company.

The aim of this study is to examine empirically the association between Days Inventory Outstanding and firm performance among energy listed companies in Saudi Arabia for the period ranging from 2013 to 2019. To the best of our knowledge that a study linking DIO with firm performance in Saudi Arabia does not exist. This study expects that there is a negative association between DIO and firm performance as follows:

$\mathrm{H}_{1}$ : There is a negative relationship between DIO and firm performance ROA.

$\mathrm{H}_{2}$ : There is a negative relationship between DIO and firm performance ROE.

The following sections of the paper are organized as follows. The data collection and research design are highlighted in Section 2. The results and discussions are illustrated in Section 3. Conclusions and implications were discussed in the final section, Section 4.

\section{Data collection and research design}

\subsection{Sample selection and data collection}

The sample of this study encompasses of 21-year observations of the energy industry. The data were collected from the energy listed companies in Saudi Stock Exchange (Tadawul) for the years ranging from 2013 to 2019. The data were collected manually from the annual reports of the companies as depicted in Table 1.

Table 1

Sample Selection from 2013 to 2019

\begin{tabular}{lc}
\hline Companies & Totals \\
\hline Total listed companies & 5 firms \\
Number of years observed & 7 years \\
Total observation & 35 \\
Missing data & $(14)$ \\
\hline Final sample & 21 \\
\hline
\end{tabular}

\subsection{Regression model and definition of variables}

Ordinary-Least Square OLS regression is used to estimate the associations between DIO and firm performance of energy listed companies in Saudi Arabia for the period ranging from 2013 to 2019. The functional equation of the OLS model is as follows:

$$
\begin{aligned}
& R O A=\beta_{0}+\beta_{1} D I O+\beta_{2} F S I Z E+\beta_{2} L E V+e \\
& R O E=\beta_{0}+\beta 1 D I O+\beta 2 F S I Z E+\beta 2 L E V+e
\end{aligned}
$$


where $R O A$ and $R O E$ are the dependent variables and represent Return on Assets and Return on Equites, respectively. In addition, DIO, FSIZE and LEV are Days of Inventory Outstanding, $\log _{10}$ of total assets and Total assets/total liabilities, respectively. Finally, $e$ represents error term.

\section{Results and discussions}

\subsection{Summary statistics}

Table 2 predicts the mean, standard deviation, minimum and maximum of each variable in the sample data set.

\section{Table 2}

Descriptive statistics

\begin{tabular}{lcccc}
\hline Panel A: Independent variables & & & & \\
\hline Continuous Variables & Mean & Std.Deviation & Minimum & Maximum \\
\hline DIO & 20 & 12 & 4 & 37 \\
FSIZE & 12083001698 & 20639349496 & 228699 & 74029648000 \\
LEV & 10.154 & 18.931 & .000 & 65.890 \\
\hline Panel B: Dependent variable & & & & \\
\hline ROA & 1.9189 & 3.923 & $-3.360-$ & 12.560 \\
ROE & 2.624 & 7.635 & $-16.77-$ & 23.25 \\
\hline
\end{tabular}

In Table 2; panel A shows that the mean of the days' inventory outstanding DIO is 20 days and the range is between 4 and 37 days with a standard deviation of 12 . The average of the firm size FSIZE is S.R 12083001698 and it ranges from S.R 228699 to S.R 74029648000 with a standard deviation of 20639349496. As for the leverage $L E V$, the average is 10.154 and it ranges from .000 to 65.890 with a standard deviation of 7.635. In Table 2; panel B illustrates that the mean of the ROA is 1.9189 and it ranges from -3.360 to 12.560 with a standard deviation of 3.923. As for the ROE, the average is 2.624 and it ranges from -16.77 to 23.25 with a standard deviation of 7.635 .

\subsection{Correlation analysis}

As for the Variance Inflation Factor (VIF), Table 3 reports the results as follows:

Table 3

Variance Inflation Factor (VIF)

\begin{tabular}{lcc}
\hline Variables & Tolerance & VIF \\
\hline DIO & .269 & 3.718 \\
FSIZ & .154 & 6.481 \\
LEV & .374 & 2.674 \\
\hline
\end{tabular}

Table 3 illustrates that the largest VIF value belongs to the firm size FSIZE which is 6.481, implying that the sample has no multicollinearity, since none of the VIF values is up to 10 (Hair et al., 2006).

\subsection{Regression results and discussions}

For the purpose of examining the association between DIO and firm performance, Ordinary-Least Square (OLS) was utilized. As shown by Tables 4 and 5, the $R^{2 s}$ for the Models 1 and 2 are .823 and .591 , respectively. This implies that Model 1 has explained $82.3 \%$ and Model $1 \mathrm{~b}$ has explained $59.1 \%$ of the total variance in the firm economic value.

Table 4

Model Summary - Model 1- ROA

\begin{tabular}{ccccc}
\hline Model & R & R Square & Adjusted R Square & Std. Error of the Estimate \\
\hline 1 & .922 & .849 & .823 & .251 \\
\hline
\end{tabular}


Table 5

Model Summary - Model 2- ROE

\begin{tabular}{ccccc}
\hline Model & R & R Square & Adjusted R Square & Std. Error of the Estimate \\
\hline 1 & .808 & .653 & .591 & .375 \\
\hline
\end{tabular}

Tables 6 and 7 depict that the $F$-values for the Models 1 and 2 were statistically significant at the $1 \%$ level which means that the overall models can be interpreted.

Table 6

ANOVA Analysis - Model 1- ROA

\begin{tabular}{ccccccc} 
& Model & Sum of Squares & df & Mean Square & F & Sig. \\
\cline { 2 - 7 } 1 & Regression & 6.052 & 3 & 2.017 & 31.979 & .000 \\
\cline { 2 - 7 } & Residual & 1.072 & 17 & .063 & & \\
\hline
\end{tabular}

Table 7

ANOVA Analysis - Model 2-ROE

\begin{tabular}{ccccccc}
\hline & Model & Sum of Squares & df & Mean Square & F & Sig. \\
\cline { 2 - 7 } 1 & Regression & 4.500 & 3 & 1.500 & 10.642 & .000 \\
\cline { 2 - 7 } & Residual & 2.396 & 17 & .141 & & \\
\hline
\end{tabular}

Tables 8 and 9 display the Pooled OLS regression results. Tables 8 and 9 show that there is a significantly negative association between $D I O$ and ROA ( $\beta=-.666, t=-3.673, P=.002$, one-tailed significance). This result demonstrates that the largest the DIO value, the lower the firm's performance. Therefore, hypothesis $\mathrm{H}_{1}$ is supported.

Table 8

Pooled OLS regression - Model 1- ROA

\begin{tabular}{lcccccc}
\hline Variables & $\begin{array}{c}\text { Expected } \\
\text { sign }\end{array}$ & Coeff. & $\boldsymbol{t}$ & $\boldsymbol{p}$-value & Tolerance & VIF \\
\hline (Constant) & & & 5.083 & .000 & & \\
Test variable & - & -.666 & -3.673 & .002 & .269 & 3.718 \\
DIO & & & & & & \\
Control variables & & .217 & .906 & .377 & .174 & 6.481 \\
FSIZE & & -.616 & -4.006 & .001 & .374 & 2.674 \\
LEV & & & & & & \\
\hline
\end{tabular}

Table 9

Pooled OLS regression - Model 2- ROE

\begin{tabular}{|c|c|c|c|c|c|c|}
\hline Variables & $\begin{array}{c}\text { Expected } \\
\text { sign }\end{array}$ & Coeff. & $t$ & $p$-value & Tolerance & VIF \\
\hline (Constant) & & & 2.833 & .011 & & \\
\hline \multicolumn{7}{|c|}{ Test variable } \\
\hline DIO & - & -.700 & .021 & .021 & .269 & 3.718 \\
\hline \multicolumn{7}{|c|}{ Control variables } \\
\hline FSIZE & & .252 & .694 & .497 & .174 & 6.481 \\
\hline LEV & & -.481 & -2.058 & .055 & .374 & 2.674 \\
\hline
\end{tabular}

Tables 8 and 9 display a significantly negative association between $D I O$ and ROE $(\beta=-.700, t=-021, P=.021$, one-tailed significance). This result demonstrates that the largest the DIO value, the lower the firm's performance. Therefore, hypothesis $\mathrm{H}_{2}$ is accepted. These results indicate that the energy companies incorporating in Saudi Arabia were not been able to translate their inventory into sales quickly and were keeping obsolete inventory. 
The study was an assessment of the impact of improving the days of inventory outstanding against the performance of a company. The focus of the study was on energy companies within Saudi Arabia. From the region, a total of 21 companies was identified with 21 companies' participants involved and their databases were examined from 2013 until 2019. Based on a Pooled OLS Regression analysis, it was identified that DIO has a negative relationship with the company's financial performance. As such, from the results, it is possible to conclude that energy companies within the said region are expected to make significant improvements for their inventory management by implementing various techniques. Some of the techniques include establishing proper planning and forecasting strategies for inventory, developing innovative marketing strategies, improving the pricing strategies, establishing the best product mix, and at the same targeting the top-selling products.

In the process of conducting the study, some limitations were noted. The model employed for the study has been limited to Saudi Arabia, however, it can also be applied in another GCC and Middle East nations to establish for validity. In fact, it can help to discover several opportunities by considering the corporate governance and firm-level characteristics such as the influence of the board of directors' characteristics and ownership structures. In fact, using the model to expand research to this evidence base can provide financial experts, investors, account regulators and companies among other stakeholders with an indepth insight of the associations between DIO and a company's performance.

\section{Acknowledgement}

This publication was supported by the Deanship of Scientific Research at Prince Sattam bin Abdulaziz University, Alkharj, Saudi Arabia.

\section{References}

Abd Karim, N., Nawawi, A., \& Salin, A. S. A. P. (2018). Inventory control weaknesses-a case study of lubricant manufacturing company. Journal of Financial Crime.

Abioro, M. (2013). The impact of cash management on the performance of manufacturing companies in Nigeria. Uncertain Supply chain management, 1(3), 177-192.

Burgess, K., Singh, P. J., \& Koroglu, R. (2006). Supply chain management: a structured literature review and implications for future research. International Journal of Operations \& Production Management, 26(7), 703-729.

Cheung, F. M., Cheung, S. F., \& Zhang, J. (2004). Convergent validity of the Chinese Personality Assessment Inventory and the Minnesota Multiphasic Personality Inventory-2: Preliminary findings with a normative sample. Journal of Personality Assessment, 82(1), 92-103.

CIMA (2002). Preparing cash budget. Retrieved January 20, 2012, from http://www.cimaglobal.com/Documents/Imported Documents/article_web_nov02.pdf

Eroglu, C., \& Hofer, C. (2011). Lean, leaner, too lean? The inventory-performance link revisited. Journal of Operations Management, 29(4), 356-369.

Fullerton, R.R., \& Wempe, W.F. (2009). Lean manufacturing, non-financial performance measures, and financial performance. International Journal of Operations \& Production Management, 29(3), 214-240.

Gallagher, T. (2000). Financial Management Principle \& Practice (2nd Ed.) New Jersey: Prentice Hall Inc.

Jarrad, V. T. (2000). Corporate cash management, excess cash and acquisitions. New York: Garland Publishing, Inc.

Koumanakos, D. P. (2008). The effect of inventory management on firm performance. International Journal of Productivity and Performance Management, 57(6), pp. 355-369.

Lambert, D. M., García-Dastugue, S. J., \& Croxton, K. L. (2005). An evaluation of process-oriented supply chain management frameworks. Journal of Business Logistics, 26(1), 25-51.

Lin, K. P., Tseng, M. L., \& Pai, P. F. (2018). Sustainable supply chain management using approximate fuzzy DEMATEL method. Resources, Conservation and Recycling, 128, 134-142.

Lwiki, T., Ojera, P. B., Mugenda, N. G., \& Wachira, V. K. (2013). The impact of inventory management practices on financial performance of sugar manufacturing firms in Kenya. International Journal of Business, Humanities and Technology, 3(5), 75-85.

Marota, R., Ritchi, H., Khasanah, U., \& Abadi, R. F. (2017). Material flow cost accounting approach for sustainable supply chain management system. International Journal of Supply Chain Management, 6(2), 33-37.

Mauchi, F. (2011). The effectiveness of cash management policies: a case study of Hunyani flexible products. International Research Journal, 2(7), 1299-1305.

Nguyen, V. (2020). Human capital, capital structure choice and firm profitability in developing countries: An empirical study in Vietnam. Accounting, 6(2), 127-136.

Platt, G (2003). World's best treasury and cash management providers. Global Finance Journal, 14(7), 35-40. 
Sahari, S., Tinggi, M., \& Kadri, N. (2012). Inventory management in Malaysian construction firms: impact on performance. SIU Journal of Management, 2(1), 59-72.

Steven, A. B., \& Britto, R. A. (2016). Emerging market presence, inventory, and product recall linkages. Journal of Operations Management, 46, 55-68.

Swamidass, P. M. (2007). The effect of TPS on US manufacturing during 1981-1998: inventory increased or decreased as a function of plant performance. International Journal of Production Research, 45(16), 3763-3778.

Tuller, L. W. (2008). Finance for non-financial managers and small business owners (2 ${ }^{\text {nd }}$ ed.). Canada, Adams Business.

Warrad, L., \& Khaddam, L. (2020). The effect of corporate governance characteristics on the performance of Jordanian banks. Accounting, 6(2), 117-126.

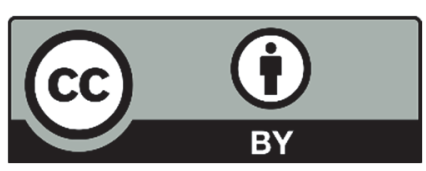

(C) 2020 by the authors; licensee Growing Science, Canada. This is an open access article distributed under the terms and conditions of the Creative Commons Attribution (CC-BY) license (http://creativecommons.org/licenses/by/4.0/). 